\title{
UTICAJ TIMSKIH ULOGA NA MOTIVACIJU ZA RAD U TIMU U KOMPANIJI ,fSD”U NOVOM SADU
}

\section{THE IMPACT OF TEAM ROLES ON MOTIVATION TO WORK IN TEAM IN A COMPANY ,fSD”, IN NOVI SAD}

\author{
Mina Čudanov, Leposava Grubić Nešić, Fakultet tehničkih nauka, Novi Sad
}

\begin{abstract}
Oblast - INDUSTRIJSKO INŽENJERSTVO I MENADŽMENT

Kratak sadržaj - Može se reći da je timski rad ključna komponenta produktivnosti, efikasnosti, zadovoljstva poslom $i$ rezultata. Više ljudi, više zna, može i postiže nego pojedinac, ma koliko sposoban bio. Da bi tim bio uspešan neophodno je da članovi u timu vrše različite uloge. $U$ ovom radu se analizira uticaj timskih uloga na motivaciju za rad u timu.
\end{abstract}

Ključne reči: zaposleni, timski rad, timovi, timske uloge, motivacija za rad, istraživanje

\begin{abstract}
It can be said that teamwork is a key component of productivity, efficiency, job satisfaction and results. More people, know more, can achieve from an individual, no matter how capable he is. In order for the team to succeed, it is essential that team members perform different roles. This paper analyzes the impact of team roles on motivation for teamwork.
\end{abstract}

Keywords: employees, team work, teams, team roles, motivation for work, research

\section{UVOD}

Zbog toga što je savremeno poslovanje postalo sve složenije neophodno je tragati za timovima koji će biti sastavljeni od članova koji se međusobno nadopunjavaju umesto za savršenim pojedincima.U tom smislu možemo reći da je tim grupa ljudi koji poseduju komplementarne veštine, koji imaju zajedničku svrhu delovanja i zajedničke ciljeve za čije dostizanje imaju zajedničku odgovornost. Mnoge studije su pokazale kako čak i naznaka da smo deo tima povećava motivaciju i zadovoljstvo na radnom mestu. To utiče na želju za ostajanjem u timu i poboljšava izvršavanje radnih zadataka. Povratna informacija o zajedničkim uspesima ili neuspesima, znanje o zajedničkom rezultatu i sistem nagrađivanja koji vrednuje tim, a ne pojedince u njemu, podstiče na motivaciju za zajedničkim radom.

\section{TIMSKI RAD I TIMSKE ULOGE}

Pod timom se podrazumeva poseban oblik formalne organizacije zajedničkog rada manjeg ili većeg broja ljudi, koje povezuju postavljeni zadaci i ciljevi, planirani poslovi i isti ili približno isti motivi i interesi.

\section{NAPOMENA:}

Ovaj rad proistekao je iz master rada čiji mentor je bila dr Leposava Grubić Nešić, red. prof.
Timski rad je metoda koja omogućava nekolicini osoba sa zajedničkim ciljem da svoje sposobnosti najbolje iskoriste međusobnim dopunjavanjem svojih veština $i$ iskustava. Timski rad je zajednički rad grupe ljudi različitog obrazovanja na rešavanju istog problema (zadatka), na istom mestu i u isto vreme.

Transformacija sa individualnog na timski rad usmerava zaposlene da sarađuju jedni s drugima, dele informacije, suočavaju se s razlikama i podrede lične interese za veće dobro tima i korist preduzeća.

Osim zajedničkog pristupa i uzajamnog dopunjavanja uloga, komplementarnosti znanja i veština kao i posvećenost zajedničkoj svrsi delovanja što timskom radu daje identitet, timski rad mora posedovati zajedničku odgovornost kako osećaja odgovornosti svakog člana tima prema timu tako i tima prema svakom članu. Može se reći da je timski rad ključna komponenta produktivnosti, efikasnosti, zadovoljstva poslom i rezultata [1]. Više ljudi, više zna, može i postiže nego pojedinac, ma koliko sposoban bio. Stvaranjem timova i unapređenjem timskog rada, mnoge kompanije su popravile svoje poslovanje, izašle iz krize ili zadržale svoju prednost na tržištu.

Timski rad i značaj timova se u svetu kontinuirano (posebno u novije vreme) proučava, prati i razvija. Razvojem i upravljanjem timovima, postiže se u kompaniji bolji stepen razumevanja, saradnje, konsultovanja, preduzimanja akcija, donošenja odluka, timski duh i kvalitetniji rad. Timski rad je mnogo više od stručno tehničke saradnje, jer kroz sinergijske efekte donosi bolje rezultate za kratko vreme s manje stresnih situacija. Sve ovo se odražava i u profitu kompanije i u motivaciji zaposlenih.

Sinergija ili kohezivnost tima jeste važan pokazatelj koliki uticaj ima grupa na svoje pojedinačne članove. Što je grupa povezanija i što je kod članova grupe osećaj privrženosti timu jače izraženo, to je veći uticaj grupe. U timovima veće kohezivnosti tj sinergije ima manje tenzija i nesporazuma nego u grupama sa manjim stepenom kohezivnosti [2].

Istraživanjem na području timskog rada, $\mathrm{dr}$ Belbin $(d r$ Meredith Belbin) razvio je model timskih uloga.

\section{ROĐENI VOĐA-KOORDINATOR:}

Daje svoj pečat i kontroliše način na koji grupa pokušava da ostvari svoje ciljeve. Sposoban je da uspešno iskoristi kvalitete koje grupa poseduje. Zna koje su jake, a koje su slabe tačke članova grupe i u stanju je da iskoristi prednosti i potencijale svakog pojedinca u grupi. Odlike: uravnotežen, dominantan, ekstrovertan. 


\section{OSOBA OD AKCIJE - MODELATOR - POKRETAČ:}

Oblikuje način na koji se koriste potencijali grupe. Drži pažnju usmerenu na određivanje ciljeva i prioriteta, vodi grupnu diskusiju i oblikuje rezultate grupnih aktivnosti. Odlike: neumoran, dominantan, ekstrovertan, impulsivan, lako se iznervira. Želi brzo da dođe do rezultata. Poseduje takmičarski duh, arogantan je, ali zahvaljujući njemu zadaci bivaju obavljeni.

\section{OSOBA SA IDEJAMA - IDEJOTVORAC - \\ KREATIVAC:}

Predlaže nove ideje i strategije, pojedinačno obrađuje najvažnije probleme, pokušava da nametne svoje sopstvene ideje, koristeći grupni pristup problemu (na bazi konfrontacije). Odlike: dominira, inteligentan, introvertan. Dobar u sagledavanju celovite slike.

OSOBA ZA KONTAKTE-ISTRAŽIVAČ:

Istažuje, analizira i sabira informacije o idejama, dostignućima i delatnostima van grupe. Ostvaruje veze sa ljudima koje mogu biti korisne za grupu,sposoban je da vodi pregovore. Odlike: uravnotežen, dominantan, ekstrovertan. Posatične inovacije, dobar inprovizator.

SNALAŽLJIVI ORGANIZATOR- REALIZATORIZVOĐAČ:

Koncepte i planove pretvara u praktičnu akciju. Zahvaljujući njemu projekti i planovi se i praktično primenjuju. Voli tačnost i doslednost, ne voli kada se planovi menjaju. Staložen, pouzdan, razuman, izvršva zadatke. Ima disciplinovan i dobro organizovan pristup. Imaju izražen osećaj samokontrole i discipline.

\section{SUDIJA-PROCENITELJ:}

Analizira problem, procenjuje ideje i predloge. Zahvaljujući njemu grupa ne prenagljuje i donosi dobro peomišljenje odluke.

Odlike: inteligentan, uravntežen, introvertan.

Najobjektivniji je, celovita ličnst, ne unosi emocije,voli da ima vremena za razmišljanje. Najbolji su u analiziranju problema i procenjivanju ideja i sugestija.

\section{ČOVEK TIMA:}

Podržava članove grupe, u slučaju greške uvek održava visok moral grupe, sposoban je da izbegne konflikt, stvara timski duh, osnažuje saradnju i komunikaciju u grupi.

Odlike: ekstrovertan, uravnotežen, nema veliku potrebu za dominacijom i rivalstvom, saosećajan.

Odan je grupi.Timski radnik zna da sluša i odgovori na potrebe drugih, izglađuje nesporazume, diplomata je.

\section{PERFEKCIONISTA-FINIŠER-DOVRS̆ILAC:}

Usmeren je na specifične akcije: privođenje zadataka kraju u okviru određenog roka obezbeđvanje rezultata najvišeg kvaliteta. Može biti težak u kontekstima, zbog toga što se gubi u detaljima koji nisu važni u izvođenju zadataka. Uvek je svestan ciljeva.

Odlike: težak, napet, introvertan, disciplinovan. Svestan, odgovoran, pouzdan, dovodi posao do cilja, polira krajnji učinak.

Finišeri su one osobe koje ne žele da započinju ništa što ne mogu da završe.

\section{POJAM MOTIVACIJE}

Motivacija (lat. Movere - pokret) se definiše kao proces pokretanja ili podsticanja ljudske aktivnosti koja se usmerava ka obavljanju ili ne obavljanju neke aktivnosti, odnosno postizanju ili ostvarenju određenog cilja. Predstavlja skup mentalnih procesa (nagona, potreba, želja, zahteva) koji podstiču, usmeravaju i održavaju ljudsko ponašanje ka određenom cilju. Motivacija za rad može se definisati kao spremnost zaposlenih u preduzeću da učestvuju u postizanju ciljeva tog preduzeća. Motivacija je onaj deo individualnog ponašanja koji je najosetljiviji i najpodložniji delovanju različitih faktora unutrašnje i spoljašnje okoline.

Motivacija zaposlenih po Viktoru Vrumu zavisi od tri vrste odnosa :

- $\quad$ Napor - performance. Ovaj odnos je određen očekivanjima radnika, odnosno njegovom percepcijom da će, ako uloži dovoljno napora, ostvariti određene performance.

- $\quad$ Performanse - nagrade. Ovaj odnos je određen instrumentalnošću rezultata, odnosno percepcijom radnika da će za postignute rezultate slediti određen bonus (nagrada).

- $\quad$ Nagrada - lični ciljevi zaposlenog. Ovaj odnos je regulisan valencom nagrada, odnosno visinom preferencije koju zaposleni ima prema određenoj nagradi. Valenca zavisi od stepena slaganja ličnih ciljeva i interesa zaposlenog i samih nagrada. Tako će bonus imati visoku valencu za radnika u proizvodnji ako on ceni novčanu nagradu više od ostalih.

Zaposlene treba uveriti da će njihov napor dovesti do ciljnog rezultata $\mathrm{i}$ da će oni biti sposobni da ostvare postavljene zadatke. Zaposlene takođe treba uveriti da će rezultat koji postignu sigurno dovesti do nagrade [3].

Postojanost motivacije pokazuje vreme ulaganja određenog nivoa napora u određenom pravcu. Neko može biti motivisan na izuzetno visokom nivou, ali vrlo kratko vreme dok drugi može biti motivisan na niskom nivou intenziteta ali u dužem periodu [4].

Faktori koji utiču na motivaciju zaposlenih u organizaciji mogu se svrstati u četiri kategorije:

1) Individualne karakteristike zaposlenih

2) Karakteristike organizacije

3) Karakteristike posla

4) Društvo - šire društveno okruženje

\subsection{Teorije motivacije}

Pitanje koje se odnosi na to šta zaposlene tera da efikasno rade svoj posao, odnosno pitanje motivacije je jedno do najčešćih pitanja koje menadžeri postavljaju sebi.

Oni često ne mogu da razumeju motive i potrebe zaposlenih [5].

Ono što menadžerima pomaže $u$ dobijanju odgovora na navedeno pitanje jesu teorije motivacije, koje ima momažu da razumeju potrebe zaposlenih.Klasifikacija teorija motivacije se može izvršiti na sledeći način [6]:

1.Sadržajne teorije

2.Procesne teorije 
U nastavku rada ukratko će biti objašnjene navedene teorije motivacije, kako bi se lakše razumelo šta to menadžeri treba da urade kako bi iskoristili ključni resurs u svojoj organizaciji - ljude.

Sadržajne teorije - bave se potrebama ljudi i na način njihovog zadovoljenja, odnosno ove teorije su usredsređena na uzroke koji motivišu ljude na rad.

Razlikuju se sledeće sadržajne teorije:

$\begin{array}{ll}\text { - } & \text { Teorija hiijerarhije potreba, } \\ \text { - } & \text { ERG model motivacije, } \\ \text { - } & \text { McClellandova teorija potreba } \\ \text { - } & \text { Teorija dva faktora }\end{array}$

Teoriju hijerarhije potreba ili Maslovljevu teoriju motivacije je 1954. godine definisao Abraham Maslow.

Teorija polazi od toga da ljudi imaju određene potrebe koje se mogu urediti hijerarhijski. Nakon što se zadovolji jedna potreba, njen značaj za pojedinca opada i druga potreba postaje značajnija i tako redom.Po Maslovu, realizacijom pet potreba,fiziološke potrebe,potrebe za sigurnošću,potrebe za pripadanjem I ljubavlju,potrebe za poštovanjem i samopoštovanjem, ljudi se mogu motivisati na rad.

Ova teorija je naišla na brojne kritike, jer sprovedena istraživanja nisu mogla da potvrde teoriju. Ipak, nesporna je korisnost teorije za

menadžere, zbog čega je i oni rado koriste u praksi. Teorija je pokazala da je za uspešno vođenje posla potrebno poznavati ljudske potrebe, čije zadovoljenje može uticati na uspešnost same organizacije.

C.Aldefer je pokušao da prevaziđe nedostatke predhodne teorije i definisao tzv. ERG model motivacije. Prihvativši Maslovljevo gledište o hijerarhijama potreba, definisao je sledeće tri potrebe:

1. Egzistencijalne potrebe (E - existence),

2. Potrebe povezivanja ( $\mathrm{R}$ - relatedness) $\mathrm{i}$

3. Potrebe rasta $(\mathrm{G}-$ growth).

ERG model motivacije polazi od toga da svakom zaposlenom treba pristupiti na različit način jer svako od njih ima različite vrste prioritetnih potreba. Iako je model bio na meti brojih kritika, model nudi koristan način razmišljanja u vezi sa motivisanjem zaposlenih.

Teoriju dva faktora je definisao F. Hezberg kada je 50-ih godina dvadesetog veka doao do zaključka da na zadovoljstvo/nezadovoljstvom poslom utiču dve grupe:

\section{Higijenski faktori i}

2. Motivacioni faktori.

Prisustvo ili odsustvo nezadovoljstva poslom određuju higijenski faktori, dok prisustvo ili odsustvo zadovoljstva poslom određuju motivacioni faktori.

Načinom motivisanja ljudi i neophodnim koracima koje treba preduzeti da bi se zaposleni motivisali bave se procesne teorije motivacije.

U ove teorije se ubrajaju:

$\begin{array}{ll}\text { - } & \text { Teorija očekivanja, } \\ \text { - } & \text { Integrativna teorija motivacije, } \\ \text { - } & \text { Teorija određivanja cilja, } \\ \text { - } & \text { Teorija pravednosti. }\end{array}$

\section{ISTRAŽIVANJE}

\subsection{Predmet istraživanja}

Predmet istraživanja master rada je da se odrede timske uloge i uticaj timskih uloga na motivaciju za rad u timu u kompaniji ,fSD" u Novom Sadu.

\subsection{Cilj istaživanja}

Cilj istraživanja jeste da se odredi da li timske uloge utiču na motivaciju za rad u timu u komapniji fSD u Novom Sadu.

\subsection{Hipoteze istraživanja}

Hipoteze koje su postavljene glase:

Opšte hipoteze

H1 - Postoji statistički značajan uticaj timskih uloga na motivaciju za rad

Ova opšta hipoteza može biti potvrđena pojedinačnim

hipotezama:

Pojedinačne hipoteze

H1.1 - Postoji statistički značajan uticaj timske uloge koordinatora na motivaciju za rad

H1.2 - Postoji statistički značajan uticaj timske uloge modelatora na motivaciju za rad

H1.3 - Postoji statistički značajan uticaj timske uloge realizatora na motivaciju za rad

H1.4 - Postoji statistički značajan uticaj timske uloge kreativca na motivaciju za rad.

H1.5 - Postoji statistički značajan uticaj timske uloge istraživača na motivaciju za rad.

H1.6 - Postoji statistički značajan uticaj timske uloge procenitelja na motivaciju za rad.

H1.7 - Postoji statistički značajan uticaj timske uloge timskog igrača na motivaciju za rad.

H1.8 - Postoji statistički značajan uticaj timske uloge finišera na motivaciju za rad

\subsection{Rezultati straživanja}

$\mathrm{Na}$ osnovu dobijenih rezultata iz upitnika vrednovanje uslova rada i faktora koji utiču na povećanje stepena motivacije zalaganja na poslu, uticaj dobrih rukovodilaca na nivo zalaganja na poslu pokazao se ključnim.

Naime, $78 \%$ ispitanika izjasnilo se da dobri rukovodioci u velikoj meri utiču na motivaciju za povećanjem zalaganja na poslu. Kada je u pitanju korelacija između timskih uloga i motivacije, povezanost timskih uloga osnivača ideje,procenjivača i finišera sa motivacijom nije se pokazala značajnom,dok su se ostale uloge kao što su snalažljivi organizator, rođeni vođa, osoba od akcije, istraživač resursa, čovek tima pokazale značajnom.

Ispitivanje uticaja timskih uloga na motivaciju ispitanika izvršeno je višestrukom regresijskom analizom. Zaključuje se da timske uloge imaju statistički značajan doprinos motivaciji.

H1: Postoji statistički značajan uticaj timske uloge koordinatora na motivaciju za rad je potvrđena. Timska uloga rođeni vođa - koordinator pokazuje statistički značajan pozitivan uticaj na motivaciju. Sa izraženošću uloge koordinatora tima raste i motivacija za rad. Na osnovu ovog rezultata prihvata se prva hipoteza. 
H2: Postoji statistički značajan uticaj timske uloge moderatora na motivaciju za rad je potvrđena. Timska uloga moderator - osoba od akcije takođe je pokazala statistički značajan uticaj na motivaciju. Rast izraženosti uloge moderatora prati rast motivacije. $\mathrm{Na}$ osnovu ovog rezultata prihvata se druga hipoteza

H5: Postoji statistički značajan uticaj timske uloge istraživača resursa na motivaciju za rad je potvrđena. Istraživač resursa pokazao je značajan uticaj na motivaciju. Sa rastom izraženosti ove timske uloge raste $i$ motivacija. $\mathrm{Na}$ osnovu ovog rezultata prihvata se 5 . hipoteza.

H7: Postoji statistički značajan uticaj timske uloge timskog igrača na motivaciju za rad je potvrđena. Timski igrač takođe značajno utiče na motivaciju za rad. Sa izraženošću ove timske uloge raste i motivacija za rad. $\mathrm{Na}$ osnovu ovih rezultata prihvata se 7 . hipoteza.

H3: Postoji statistički značajan uticaj timske uloge realizatora na motivaciju za rad se odbacuje. Iako je uloga realizatora pokazala statistički značajnu povezanost sa motivacijom značajan uticaj na motivaciju je izostao. Na osnovu ovog rezultata odbacuje se 3 . hipoteza.

H4: Postoji statistički značajan uticaj timske uloge osnivač ideje na motivaciju za rad se odbacuje

H6:Postoji statistički značajan uticaj timske uloge procenjivač na motivaciju za rad se odbacuje

H8: Postoji statistički značajan uticaj finišera timskog igrača na motivaciju za rad se odbacuje

Ove timske uloge nisu pokazale ni značajnu povezanost kao ni uticaj na motivaciju. Na osnovu ovih rezultata odbacuje se 4.,6. i 8. hipoteza.

$\mathrm{Na}$ osnovu ovih rezultata opšta hipoteza,

Ho: Postoji statistički značajan uticaj timskih uloga na motivaciju za rad

delimičmo je potvrđena.

\section{ZAKLJUČAK}

$\mathrm{Na}$ osnovu ovog istraživanja zaključujemo da je za efikasan i produktivan timski rad važno da svi članovi doprinose timu na način koji najviše odgovara njihovim sposobnostima, sklonostima, iskustvima i da preuzmu i uloge u kojima se najbolje osećaju. Ne postoje dobre ili loše uloge u timu, nego samo one koje manje ili više odgovaraju pojedincu.

Pretpostavljam da nijedna organizacija ne može uspešno da posluje bez motivacije zaposlenih i timskog rada, što uključuje precizno određene timske uloge, prema tome kako bi kompanija došla do svog cilja, veoma bitno da se precizno odrede timske uloge članova tima. Svaki član tima mora biti zainteresovan da sagleda probleme drugih članova tima, kao i da je tu da pomogne i sarađuje, jer time se jedino može postići veća motivisanost zaposlenih.
Timska organizacija daje zaposlenima veći osećaj da mogu da utiču na radnu situaciju i povećava radnu motivaciju. Da bi motivacija članova tima bila što bolja, za svaku osobu treba pronaći baš ono što je motiviše. Ako nekoga motiviše novac, onda treba napraviti novčane nagrade u vidu bonusa za realizaciju projektnih ciljeva.

Ako nekoga motivišu tehnička dostignuća, onda treba dati ulogu na projektu koja će biti tehnički izazovna i zahtevna.

\section{LITERATURA}

[1] Milošević, B. (2007.). Umeće rada. Novi Sad.

[2] Grubić -Nešić,L.(2005). Razvoj ljudskih resursa. Novi Sad: AB Print

[3] Grindberg, D. B. (1998.). Ponašanje u organizacijama. Beograd: Želnid.

[4] Janićević N., „Organizaciono ponašanje“, Data Status, Beograd, 2008

[5]VESIĆ D., „Uloga menadžmenta u motiviciji zaposlenih“, Međunarodna naučna konferncija: Menadžment 2010.

[6]CRETO S., CRETO T., „Moderni menadžment“, Zagreb, Mate d.o.o. Zagreb, 2008.

\section{Kratka biografija}

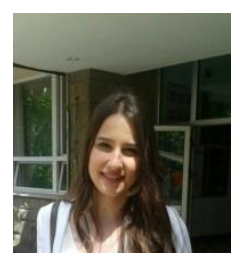

Mina Čudanov, rođena 1992. u Kikindi. Diplomirala na Fakultetu Tehničkih nauka,Univerziteta u Novom Sadu, 2017.godine i stekla zvanje diplomirani inzenjer menadžmenta. Master $\operatorname{rad}$ na Fakultetu tehničkih nauka iz oblasti Industrijskog inženjerstva i menadžmenta Menadžment ljudskih resursa odbranila je 2018. godine. 